\title{
Safety Aspects in Preparation and Handling of Infant Food
}

\author{
Dominique Turck \\ Division of Gastroenterology, Hepatology and Nutrition, Department of Pediatrics, Jeanne de Flandre Children's \\ Hospital and Lille University Faculty of Medicine, Lille, France
}

\section{Key Words}

Breastfeeding • Infant formula • Infant food - Preparation •

Handling $\cdot$ Cronobacter spp. $\cdot$ Enterobacter sakazakii

\begin{abstract}
Powdered infant formula (PIF) can become contaminated during production with harmful bacteria such as Cronobacter spp. (formerly Enterobacter sakazakii). Inadequate conditions of preparation and handling of PIF can therefore exacerbate the risk of severe infection, especially in preterm infants. The WHO emphasized three main interventions for preparation and handling of PIF: (1) to dilute the powdered milk in water at a temperature of at least $70^{\circ} \mathrm{C}$ to inactivate Cronobacter spp.; (2) to consume milk right after each preparation, and (3) to store reconstituted milk at $<5^{\circ} \mathrm{C}$. The European Society for Pediatric Gastroenterology, Hepatology and Nutrition (ESPGHAN) and the French Food Safety Agency (Afssa) disagree with the heating process because of possible adverse effects on nutrients and the risk of severe burns. In home settings, PIF should be prepared fresh for each meal and be kept warm in bottle warmers or thermos bottles. In institutional settings, written guidelines for preparation and handling of PIF should be established. The use of sterile liquid formula is encouraged for healthy newborn
\end{abstract}

\section{KARGER}

Fax +4161306 1234

E-Mail karger@karger.ch

www.karger.com
(C) 2012 S. Karger AG, Basel

0250-6807/12/0603-0211\$38.00/0

Accessible online at:

www.karger.com/anm infants in maternity wards; PIF should be prepared on a daily basis. Safe infant feeding involves the production of microbiologically cleaner infant formula by industry, and both education and support for the caregivers in preparing and handling the formula.

Copyright $\odot 2012$ S. Karger AG, Basel

\section{Introduction}

Infants are at a higher risk to develop foodborne disease because their immune system is still undergoing maturation and the protection against invasive infections afforded by their intestinal microbiota is not as effective as in adults.

\section{Breast Milk and Infant Formula}

Breast milk is the natural food for infants. It contains numerous immune-related components that offer passive protection in the gastrointestinal tract and to some extent in the upper respiratory tract, thereby protecting the breastfed infant against invasive infections [1]. In 2001, the WHO emphasized exclusive breast feeding for 6 
months and continued breastfeeding up to 2 years of age or beyond [2].

Non-breastfed infants should be fed infant formula (IF), the composition of which complies with the standards defined in the Directive 2006/141/EC of 22 December 2006 on IF and follow-on formulae and in the Directive 1999/21/EC on dietary foods for special medical purposes $[3,4]$. These two directives stress that infant and follow-on formulae shall not contain any substance in such quantity as to endanger the health of infants and young children'.

\section{Risks Related to the Use of IF}

In Europe, IF are available in 2 types: ready-to-feed liquid and powdered. Powdered IF (PIF) can become contaminated during production with harmful bacteria, even in very small amounts, such as Cronobacter spp. (formerly Enterobacter sakazakii) [5]. This is because using current technology, manufacturing processes cannot achieve the production of sterile PIF [6]. An international survey showed the presence of Cronobacter spp. in 1\% of tested follow-on formula and in $12 \%$ of infant foods and drinks [7]. The Codex alimentarius (a United Nations body tasked by FAO and WHO determining international standards for food production and safety) has published specifications for Salmonella. Specific criteria for Cronobacter spp. are not included, but come under the general category of coliforms [5].

Reconstituted PIF are excellent media for multiplication of potentially pathogenic bacteria. Inadequate conditions of preparation and handling of PIF can therefore exacerbate the risk of severe infection. In a study performed in the USA, IF prepared at bedside were 24 times more likely to show contamination than those prepared in a central location, and PIF were 14 times more likely to be contaminated than ready-to-feed formulae [8]. Spanish investigators reported that contaminated feeding bottles were the source of an outbreak of Pseudomonas aeruginosa infection in a neonatal intensive care unit [9]. Cronobacter spp. can also be found in food and beverages other than IF and milk powder [10].

Since 1958, there have been approximately 120 reported cases of Cronobacter spp. infection in infants and children $<3$ years of age. Outbreaks were observed in Belgium in 1998 and in New Zealand and France in 2004. The population at greatest risk for Cronobacter spp. infection includes preterm infants born before 36 weeks of gestational age up to a post-term age of 4-6 weeks, term in- fants hospitalized in level 2 and 3 neonatal intensive care units, and immunocompromized infants at any age. Infections have been observed not only in hospitals but also in outpatient settings [11]. Six PIF-associated Salmonella outbreaks have been described since 1995 across Canada, France, Korea, Spain, UK, and USA. The most recent was an outbreak of Salmonella agona that occurred in France in 2005, involving 141 infants $<1$ year of age.

The effect of temperature on the growth of Cronobacter spp. is striking. Minimal and maximal growth temperature are $5.5-8^{\circ} \mathrm{C}$ and $47^{\circ} \mathrm{C}$, respectively. Therefore, at room temperature, there is a potential for rapid growth of Cronobacter spp. [5].

\section{Recommendations of Official Bodies}

\section{Breast Milk}

After collection, any break in the cold chain must be avoided. There are two storage options: (1) storage in the refrigerator: the milk may be stored at a temperature not exceeding $4^{\circ} \mathrm{C}$ for not more than $48 \mathrm{~h}$; (2) storage in the freezer: milk stored in the freezer $\left(-18^{\circ} \mathrm{C}\right)$ can be stored for 4 months with no detrimental effects [12].

\section{Infant Formula}

The WHO introduced the Five Keys to Safer Food poster in 2001. It consists of simple headings that are more easily remembered, specific suggestions for improvement, and reasons behind the suggested measures. Copies are available at: http://www.who.int/foodsafety/ publications/consumer/5keys/en/index.html. The WHO has also published the Five Keys to Safer Food Manual. Copies are available at: http://www.who.int/foodsafety/ consumer/5keysmanual/en. The components of the Five Keys to Safer Foods are: (1) keep clean; (2) separate raw and cooked; (3) cook food thoroughly; (4) keep food at safe temperature, and (5) use safe water and raw materials.

The WHO suggested three main interventions for preparation and handling of IF: (1) to dilute the powdered milk in water at a temperature of at least $70^{\circ} \mathrm{C}$ to inactivate Cronobacter spp.; (2) to consume milk right after each preparation, and (3) to store reconstituted milk at $<5^{\circ} \mathrm{C}$ [13]. Similar recommendations have been put forward by the UK Department of Health, the Finnish Food Safety Authority, Health Canada [14], and the European Food Safety Authority [15]. However, the untoward consequences of the use of hot water can lead to the formation of curds, the risk of burns for households (especially 
children), and the loss of $10-25 \%$ of some nutrients, mainly vitamins (thiamine, vitamins B1, B6 and B12, folic acid, and vitamin C) [12]. The Committee on Nutrition of the European Society for Pediatric Gastroenterology, Hepatology and Nutrition (ESPGHAN CoN) [11] and the French Food Safety Agency (Afssa) [12] disagree with the use of boiling water and of heating of reconstituted formula to temperatures close to the boiling point because of possible adverse effects on nutrients and the risk of severe burns.

ESPGHAN CoN recommended that, in home settings, PIF should be prepared fresh for each meal and that IF should never be kept warm in bottle warmers or thermos bottles [11]. In institutional settings, written guidelines for preparation and handling of IF should be established, and their implementation should be monitored; the use of sterile liquid formula is encouraged for healthy newborn infants in maternity wards; if formula needs to be prepared in advance, it should be prepared on a daily basis and kept at $4^{\circ} \mathrm{C}$ or below for not more than $30 \mathrm{~h}$. The storage temperature should be monitored $[11,16]$. Studies comparing WHO/EFSA and ESPGHAN/Afssa recommendations are urgently needed.

\section{Knowledge of Parents and Caregivers}

Information of parents is also a critical issue. In a recent US survey, the majority of IF-feeding mothers did not receive instruction on formula preparation (77\%) or storage (73\%) from a health professional [17]. Among the mothers of the youngest infants, $55 \%$ did not always wash their hands with soap before preparing IF, 32\% did not adequately wash bottle nipples between uses, and 35\% heated formula bottles in a microwave oven. The conclusion of a recent systematic review of studies on mothers' experiences of bottle feeding was that inadequate information and support for mothers who decide to bottle feed may put the health of their babies at risk. While it is important to promote breastfeeding, it is also necessary to ensure that the needs of bottle-feeding mothers are met [18]. This issue is also underlined in the Baby Friendly Initiative [19].

\section{Conclusion}

Safe infant feeding involves the production of microbiologically cleaner IF by industry, and both education and support for the caregivers in preparing and handling the formula.

\section{Disclosure Statement}

Dominique Turck received research funding from Danone and Nestlé and reimbursement of travel and hotel expenses related to ESPGHAN meeting attendance from Mead Johnson.

\section{References}

$>1$ Agostoni C, Braegger C, Decsi T, Kolacek S, Koletzko B, Michaelsen KF, Mihatsch W, Moreno LA, Puntis J, Shamir R, Szajewska H, Turck D, van Goudoever J; ESPGHAN Committee on Nutrition: Breast-feeding: a commentary by the ESPGHAN Committee on Nutrition. J Pediatr Gastroenterol Nutr 2009;49:112-125.

2 WHO (World Health Organization): 54th World Health Assembly. Infant and young child nutrition. WHA 54.2, May 18, 2001. http://apps.who.int/gb/archive/pdf_files/ WHA54/ea54r2.pdf (accessed January 17, 2012).

3 Commission Directive 1999/21/EC of 25 March 1999 on dietary foods for special medical purposes. Official J Eur Com 07.04.1999, L 139. http://eur-lex.europa.eu/LexUriServ/ LexUriServ.do?uri=CONSLEG:1999L0021: 20070119:EN:PDF (accessed January 17, 2012).
4 Commission Directive 2006/141/EC of 22 December 2006 on infant formulae and follow-on formulae. Official J Eur Union 30.12.2006, L 401/1. http://eur-lex.europa. eu/LexUriServ/LexUriServ.do?uri= OJ:L:2006:401:0001:0001:EN:PDF (accessed January 17, 2012).

5 Joint FAO/WHO Workshop on Enterobacter sakazakii and other microorganisms in powdered infant formula, Geneva, 2-5 February 2004. http://www.who.int/foodsafety/micro/jemra/meetings/feb2004/en/ (accessed January 17, 2012).

6 Khandal MC, Relj MW, Gorris LGM, Guillaume-Gentil O, van Schothorst M: Occurrence of Enterobacter sakazakii in food production environments and households. Lancet 2004;363:39-40.
7 Chap J, Jackson P, Siqueira R, Gaspar C, Park J, Osaili T, Shaker R, Jaradat Z, Hartantyo SHP, Abdiullah Sani N, Estuningsih S, Forsythe SJ: International survey of Cronobacter sakazakii and other Cronobacter spp. in follow up formulas and infant foods. Int J Food Microbiol 2009;136:185-188.

$>8$ Steele C, Short R: Centralized infant formula preparation room in the neonatal intensive care unit reduces incidence of microbial contamination. J Am Diet Assoc 2008;108:17001703.

$\checkmark 9$ Sanchez-Carrillo C, Padilla B, Marin M, Rivera M, Cercenado E, Vigil D, Sanchez-Luna M, Bouza E: Contaminated feeding bottles: the source of an outbreak of Pseudomonas aeruginosa infections in a neonatal intensive care unit. Am J Infect Control 2009;37:150154. 
10 Friedemann M: Enterobacter sakazakii in food and beverages (other than infant formula and milk powder). Int J Food Microbiol 2007;116:1-10.

-11 Agostoni C, Axelsson I, Goulet O, Koletzko B, Michaelsen KF, Puntis JWL, Rigo J, Shamir R, Szajewska H, Turck D, Vandenplas Y, Weaver LT; ESPGHAN Committee on Nutrition: Preparation and handling of powdered infant formula: a commentary by the ESPGHAN Committee on Nutrition. J Pediatr Gastroenterol Nutr 2004;39:320-322.

12 Agence française de sécurité sanitaire des aliments (French Food Safety Agency): Hygiene recommendations for the preparation, handling and storage of feeding bottles. July 2005. http://www.cclinparisnord.org/ Guides/AFSSA_bib.pdf (accessed January $17,2012)$
13 WHO (World Health Organization) and Food and Agriculture Organization of the United Nations: Safe preparation, storage and handling of powdered infant formula. Guidelines. 2007. http://www.who.int/foodsafety/publications/micro/pif_guidelines. pdf (accessed January 17, 2012).

14 Pagotto FJ, Farber JM: Cronobacter spp. (Enterobacter sakazakii): advice, policy and research in Canada. Int J Food Microbiol 2009; 136:238-245.

15 Opinion of the Scientific Panel on Biological Hazards on a request from the Commission related to the microbiological risks in infant formulae and follow-on formulae. The EFSA Journal 2004;113:1-35. http://www.efsa. europa.eu/fr/efsajournal/doc/113.pdf (accessed January 17, 2012).
16 American Dietetic Association: Pediatric Nutrition Practice Group. Infant feedings: guidelines for preparation of formula and breastmilk in health care facilities. 2003 . http://38.98.128.12/cps/rde/xchg/SID 5303FFEA-E4B8B 46C/ada/hs.xsl/nutrition_1562_ENU_HTML.htm (accessed January 17,2012 ).

17 Labiner-Wolfe J, Fein SB, Shealy KR: Infant formula-handling education and safety. Pediatrics 2008;122:S85-S90.

18 Lakshman R, Ogilvie D, Ong KK: Mothers' experiences of bottle-feeding: a systematic review of qualitative and quantitative studies. Arch Dis Child 2009;94:596-601.

19 UNICEF UK: Baby Friendly Initiative. Special situations and common complications. http://www.unicef.org.uk/BabyFriendly/ Health-Professionals/Going-Baby-Friendly/ University/University-learning-outcomes/Learning-outcomes-12-16/ (accessed January 17,2012$)$. 